\title{
DETERMINE THE REQUIRED LOG REDUCTIONS OF HUMAN INTESTINAL HELMINTH EGGS BY WASTE STABILIZATION POND: A SIMULATION FOR WASTEWATER RECYCLING IN AGRICULTURE
}

\author{
Adel S. FASKOL - PhD, Candidate, Technical University of Civil Engineering of Bucharest, Faculty of \\ Hydrotechnics, e-mail: Adel.S.Faskol@gmail.com \\ Gabriel RACOVITEANU - Professor, PhD, Technical University of Civil Engineering of Bucharest, Faculty of \\ Hydrotechnics, e-mail: Gabriel.racoviteanu@utcb.ro
}

\begin{abstract}
This paper investigates the determined the required log reductions for human intestinal helminth eggs by waste stabilization ponds as simulation as assessing of mitigating health risk to satisfy practice WHO, 2006 guidelines for the safe use of wastewater in agriculture $(\leq 0.1$ helminth egg $/ \mathrm{L}$ ) to protect the health of children under 15 years was the development of MATLAB, a computer program based waste stabilization ponds design based on parameter uncertainty and 10,000-trial Monte Carlo simulations were developed for a series of anaerobic, facultative and maturation ponds based on $95 \%$-ile of effluent $(\leq 0.1$ helminth egg/L) which the result in a health-based target. Whereas the influent of the helminth eggs (Nematode) was $(932.500 \mathrm{eggs} / \mathrm{L})$. While the treatment provided $(100 \%$ reduction/removal $)$ for the overall treatment process with total hydraulic retention time in climatic conditions of Libya it took 36.207 days in the anaerobic pond, facultative pond, first maturation pond and one of the subsequent maturation pond.
\end{abstract}

Keywords: Safe re-use wastewater practices; Nematode eggs removal in climatic conditions of Libya; PC-based Monte Carlo simulation.

\section{Introduction}

About 173 million people in the Eastern Mediterranean Region, 35\% of the entire Region, have less than the threshold level of 1000 cubic meters per capita per year. These include the countries of Bahrain, Djibouti, Egypt, Jordan, Kuwait, Libya, Morocco, Oman, Qatar, Saudi Arabia, Tunisia, the United Arab Emirates, and Yemen. Countries of the Eastern Mediterranean Region which may be considered below the water poverty line of 500 cubic metres per year total about 73 million people, $15 \%$ of the total population, and include Bahrain, Jordan, Kuwait, Libya, Oman, Qatar, Yemen, Saudi Arabia, Tunisia, and the United Arab Emirates [1].

Water for irrigation and food production constitutes one of the greatest pressures on fresh water resources. The daily drinking water requirement per person is 2-4 litres, but it takes 2,000 to 5,000 litres of water to produce one person's daily food. Agriculture is by far the largest consumer of fresh water resources, currently accounting for over 70 per cent of global withdrawals and 86 per cent of the world's total fresh water consumption [2].

It is clear that wastewater is increasingly being used worldwide, both in developing and industrialized countries, particularly in rapidly growing urban areas with large wastewater production volumes. It is important to note, however, that there is a range of types, categories and uses of wastewater, depending on its composition, its treatment, and the planned or unplanned forms of its utilization [3].

The main advantages of domestic water reuse are: (a) provision of nutrients; (b) reliability in water supply; (c) contribution to the urban food supply; (d) income generation; and (e) livelihood sustenance. These aspects are especially important for small-scale farmers who can obtain enhanced water and food security by using recycled or even raw wastewater for irrigation [4-6].

Municipal wastewater contains a variety of pathogens, reflecting the carrier state and infection levels in the community $[7,8]$. The contamination of surface water with untreated or partially treated wastewater may as a consequence lead to adverse health implications [9-11]. 


\subsection{Organisms pathogens in raw sewage}

Raw sewage contains a variety of excreted organisms and pathogens from human and animal origin, with numbers that vary depending upon the background levels of disease in the population. Disease outbreaks in affected populations result in increased concentrations of the causative agents in the wastewater. Table 1 shows ranges of concentrations for different excreted organisms that can be found in wastewater, and are related to bacteria, intestinal helminths, protozoa and viruses [12].

Table 1

Typical numbers of excreted organisms in raw sewage

\begin{tabular}{|lc|}
\hline Organism & Numbers in wastewater (per L) \\
\hline Bacteria & \\
Thermotolerant coliforms & $10^{8}-10^{10}$ \\
Campylobacter jejuni & $10-10^{4}$ \\
Salmonella spp. & $1-10^{5}$ \\
Shigella spp. & $10-10^{4}$ \\
Vibrio cholerae & $10^{2}-10^{5}$ \\
Intestinal helminths & $1-10^{3}$ \\
Ascaris lumbricoides & $1-10^{3}$ \\
Ancylostoma/Necator & $1-10^{2}$ \\
Trichuris trichiura & $1-10^{4}$ \\
Protozoa & $1-10^{2}$ \\
Cryptosporidium parvum & $10^{2}-10^{5}$ \\
Entamoeba histolytica & \\
Giardia intestinalis & $10^{5}-10^{6}$ \\
Viruses & $10^{2}-10^{5}$ \\
$\quad$ Enteric viruses & \\
Rotavirus & \\
\hline
\end{tabular}

Source: [13-16].

\subsubsection{Helminths}

Helminths are worms causing a wide variety of diseases globally called helminthiases. Helminthiases almost only occur in developing countries, particularly in areas where sanitation is low sanitation. Although helminths are not microscopic animals, their eggs, which are the infective agents, are. Helminth eggs are discharged to the environment in faeces and the oralfaecal route is the main dissemination pathway of the disease [17].

\subsubsection{Classification of the Helminths}

There are three different kinds of helminths (a) Plathelminths or flat worms, (b) Nemathelminths (Aschelminths) or non-segmented round worms, and (c) Annelida or segmented round worms (Figure 1). Those infecting humans through wastewater, sludge or faecal sludge belong only to the first two groups. Helminths are pluri-cellular worms with sizes varying from $1 \mathrm{~mm}$ to several m in length; thus, they are not microbes although their eggs are microscopic [17]. 


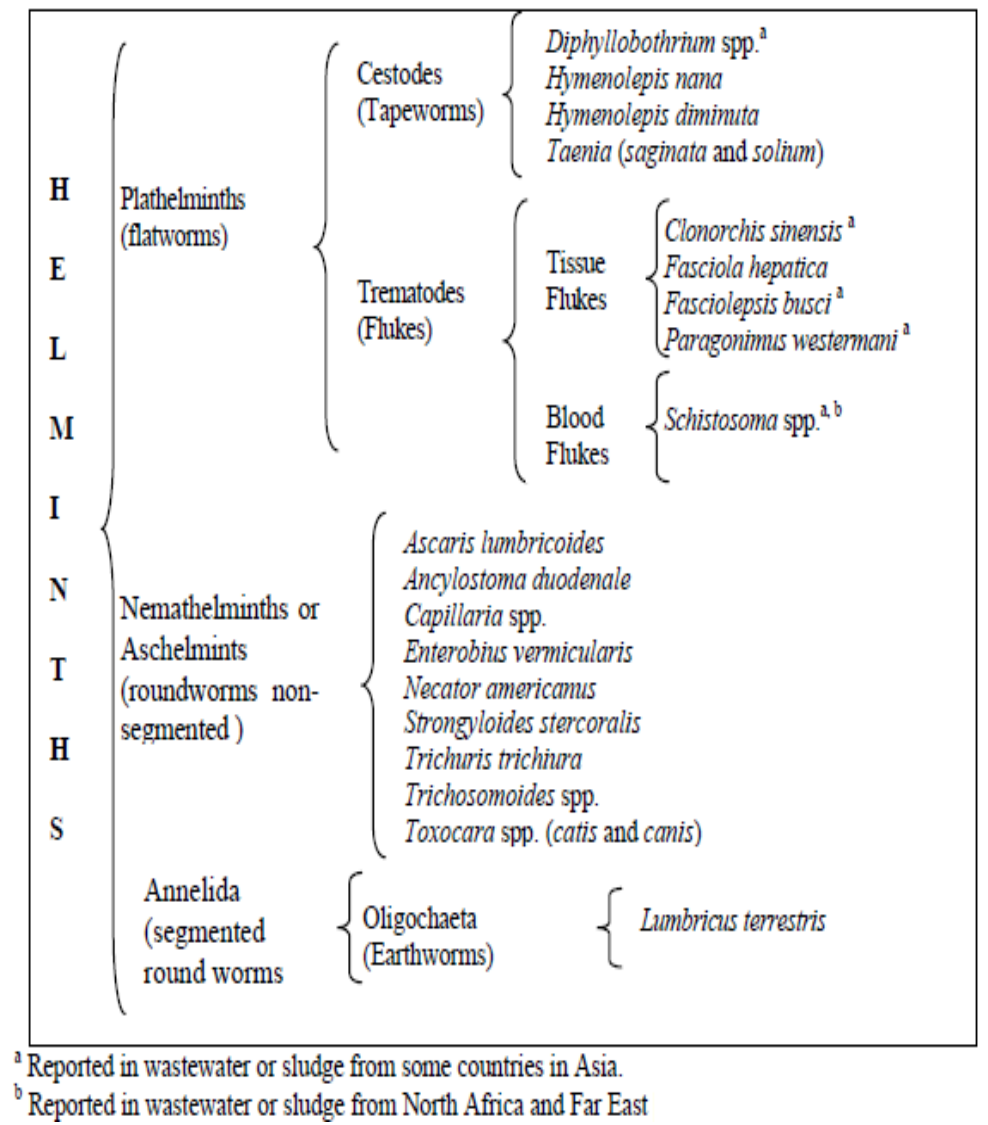

Fig. 1- Helminth classification and common genera found in wastewater and sludge [17].

\subsubsection{Helminth eggs}

A common characteristic of helminths is that they reproduce through eggs. The eggs are different in shape and size depending on the genera (Figure 2). The helminth eggs of importance in the sanitary engineering field frequently measure between 20 and $80 \mu \mathrm{m}$, although some are as long as $185 \mu \mathrm{m}$ (schistosomonas). The density of the eggs is greater than that of the water (1.056-1.237) and their structure is gelatinous making them very sticky $[17,18]$.

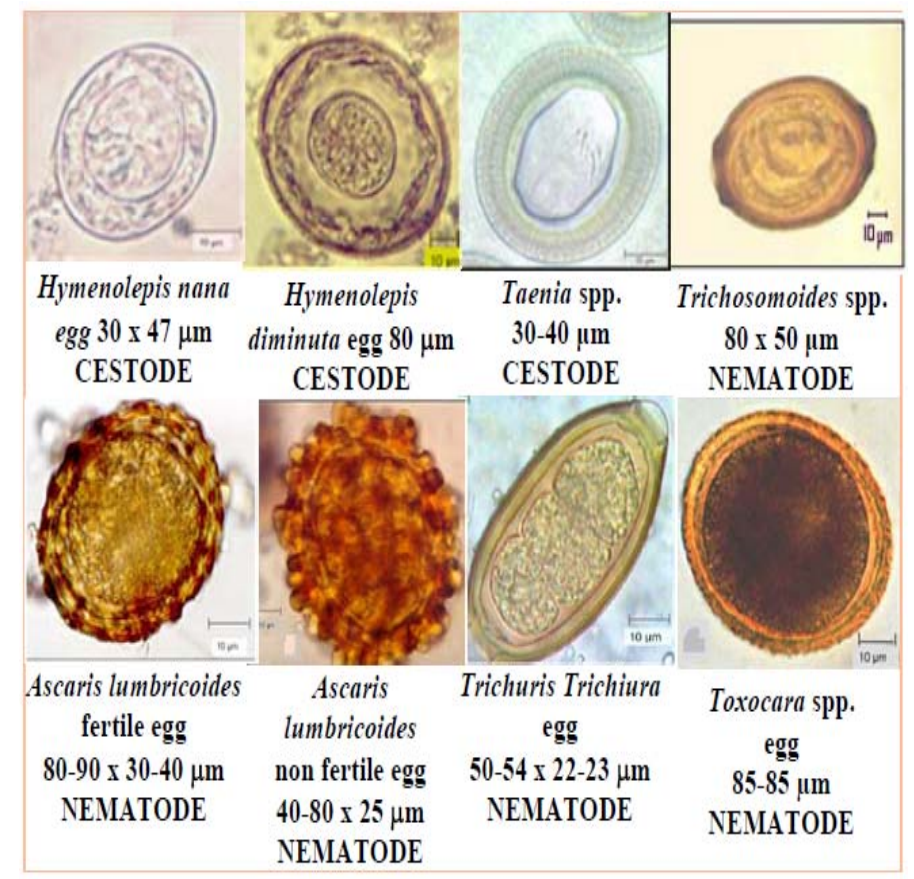

Fig. 2- Helminth eggs observed in wastewater and sludge[17,18]. 


\subsection{The basic mechanism of helminth eggs removal in waste stabilization ponds}

Removal of pathogens is considered a major advantage in using waste stabilization pond (WSP) systems for wastewater treatment $[19,20]$. Over the last decade, an increasing number of studies conducted in different countries have shown waste stabilization pond systems to be a suitable method of wastewater treatment, especially with regard to the removal of helminth parasites [15, 21-27].

The basic mechanism of egg removal in all wastewater treatment processes is by sedimentation (plain or enhanced by adsorption to solids). This implies that all factors influencing this process will affect helminth egg removal. For effective helminth egg removal, the most important design parameters are probably the number of ponds in series and the mean hydraulic retention time of each pond [28].

\subsection{Guidelines for the safe use of wastewater in agriculture}

The World Health Organization has adopted a tolerable burden of waterborne disease from consuming drinking water of $\leq 10^{-6}$ DALY per person per year (WHO, 2004). This level of disease burden can be compared with mild diarrhea at an annual disease risk of $10^{-3}$, which is equivalent to 1 occurrence in a population of 1000 , during a lifetime. Such a high level of health protection has been adopted by (WHO,2006) [29], as a tolerable burden of disease for wastewater use in agriculture, by assuming that food crops irrigated with treated wastewater, especially those eaten uncooked.

\subsubsection{Health Based -Targets for treated wastewater use in agriculture}

The health-based targets define a level of health protection that is relevant to each hazard a healthbased target can be based on an appropriate health outcome, such as the prevention of the transmission of vector-borne diseases resulting from exposures to wastewater use in agricultural practices. To achieve a health-based target, health protection measures are developed. Usually, a health-based target can be achieved through a combination of health protection measures targeted at different components of the system. Figure 3 illustrates different combinations of health protection measures that can be used to achieve the $10^{-6}$ DALYs health-based targets for excretarelated diseases.

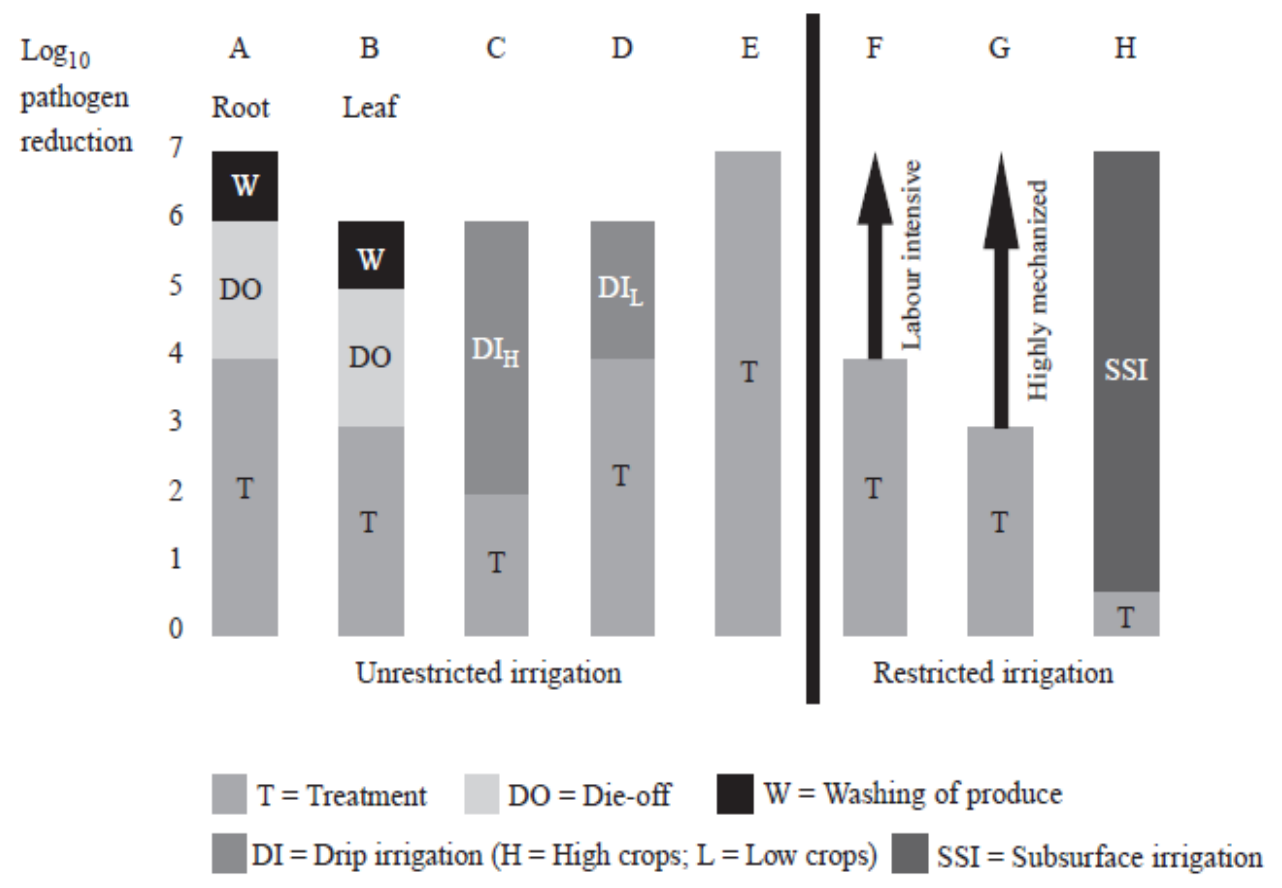

Fig. 3- Examples of options for the reduction of viral, bacterial and protozoan pathogens by different combinations of health protection measures that achieve the health-based target of $\leq 10-6$ DALYs per person per year [29]. 
Table 2 describes health-based targets for agriculture. The health-based targets for rotavirus are based on QMRA indicating the log 10 pathogen reduction required to achieve $10^{-6}$ DALY for different exposures. To develop health-based targets for helminth infections, epidemiological evidence was used.

Table 2

Health-based targets for wastewater use in agriculture

\begin{tabular}{|c|c|c|c|}
\hline Exposure scenario & $\begin{array}{l}\text { Health-based target } \\
\text { DALY (pppy) }\end{array}$ & $\begin{array}{l}\text { Log10 pathogen } \\
\text { reduction needed }\end{array}$ & $\begin{array}{c}\text { Number of helminth } \\
\text { eggs per liter }\end{array}$ \\
\hline $\begin{array}{l}\text { Unrestricted } \\
\text { irrigation: } \\
\text { Lettuce } \\
\text { Onion } \\
\text { Restricted } \\
\text { Irrigation: } \\
\text { Highly mechanized } \\
\text { Labor intensive } \\
\\
\text { Localized (drip) } \\
\text { irrigation: } \\
\text { High-growing crops } \\
\text { Low-growing crops }\end{array}$ & $\begin{array}{l}\leq 10^{-6} \\
\leq 10^{-6}\end{array}$ & $\begin{array}{l}3 \\
4\end{array}$ & $\begin{array}{l}\leq 1 \\
\leq 1 \\
\leq 1 \\
\leq 1\end{array}$ \\
\hline
\end{tabular}

This evidence demonstrated that excess helminth infections (for both product consumers and farmers) could not be measured when wastewater quality of $\leq 1$ helminth egg per litre was used for irrigation. This level of health protection could also be met by treatment of wastewater or by a combination of wastewater treatment and washing of produce to protect consumers of raw vegetables; or by wastewater treatment and the use of personal protective equipment (shoes, gloves) to protect workers. When children less than 15 years old are exposed in the fields. Either additional wastewater treatment (to achieve a wastewater quality of $\leq 0.1$ helminth egg per litre) or the addition of other health protection measures (e.g. anthelminthic treatment) should be considered [29].

\section{Materials and method}

\subsection{Location and Climate}

This study was carried on climatic conditions of Libya, were Jalu is a place of wastewater sampling. Jalu is a small municipality with a population of 18873 in 2006 . Located in the central South-East of Libya, as shown in Figure 4. The climatic conditions as showing in table 3. The main economic activity in Jalu municipality is agriculture. 


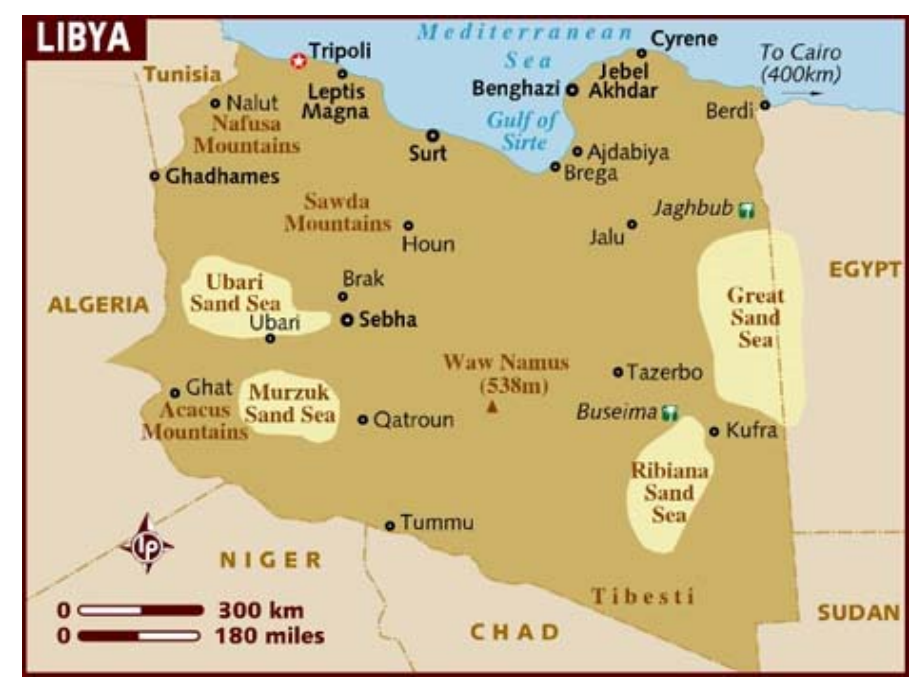

Fig. 4 - a map Jalu municipality in Libya

Table 3

The climatic conditions at Jalu, Libya

\begin{tabular}{|c|c|c|}
\hline Parameters & Lower value & Upper value \\
\hline temperature & $1^{\circ} \mathrm{C}$ & $48^{\circ} \mathrm{C}$ \\
\hline evaporation & $0.43 \mathrm{~mm} /$ day & $23.1 \mathrm{~mm} /$ day \\
\hline Net evaporation & $-3.9 \mathrm{~mm} /$ day & $23 \mathrm{~mm} /$ day \\
\hline Average Rainfall & \multicolumn{2}{|c|}{$18.4 \mathrm{~mm} /$ day } \\
\hline
\end{tabular}

Source: Libyan national meteorological center [30].

\subsection{Sample collection}

The sampling was stored in a cooler during the transfer to the laboratory. When the samples arrived at the laboratory, sample preparations for the pathogen tests were performed immediately to minimize changes in the microbiology of the samples. Examination the samples were as the American public health association standard methods for the examination of water and wastewater [31]. Wastewater analyzed included (See table 4) biological oxygen demand (BOD), chemical oxygen demand (COD), coliform bacteria (MPN/100 ml).

Wastewater composition at Jalu, Libya

\begin{tabular}{|c|c|}
\hline Parameters & Median value \\
\hline BOD (mg L-1) & 225 \\
\hline COD (mg L-1) & 249 \\
\hline $\begin{array}{c}\text { Coliform bacteria } \\
\text { (MPN/100 mL) }\end{array}$ & $11 \times 107$ \\
\hline \multirow{2}{*}{\begin{tabular}{c} 
Nematode eggs (eggs/L) \\
\cline { 2 - 2 }
\end{tabular}} & $100-1000$ \\
\hline
\end{tabular}

Note: MPN stands for: most probable number.

Source Nematode eggs content in wastewater by Ayres and Mara [32]. 


\subsection{A computer program using Monte Carlo simulation methods}

Banda and Banda et al. Have suggested that using modern methods for designing waste stabilization ponds WSP whose final effluent is to be used for the irrigation in developing countries $[33,34]$. There is commonly some degree of uncertainty about the values of the parameters used to determine required log pathogen reductions. According to Von Sperling, that Monte Carlo simulation should be used when designing WSP because it is an efficient way to manage the uncertainty of the input design variables and coefficients. [35]. In this way, was the development of MATLAB a computer program for design waste stabilization ponds (See flowchart).

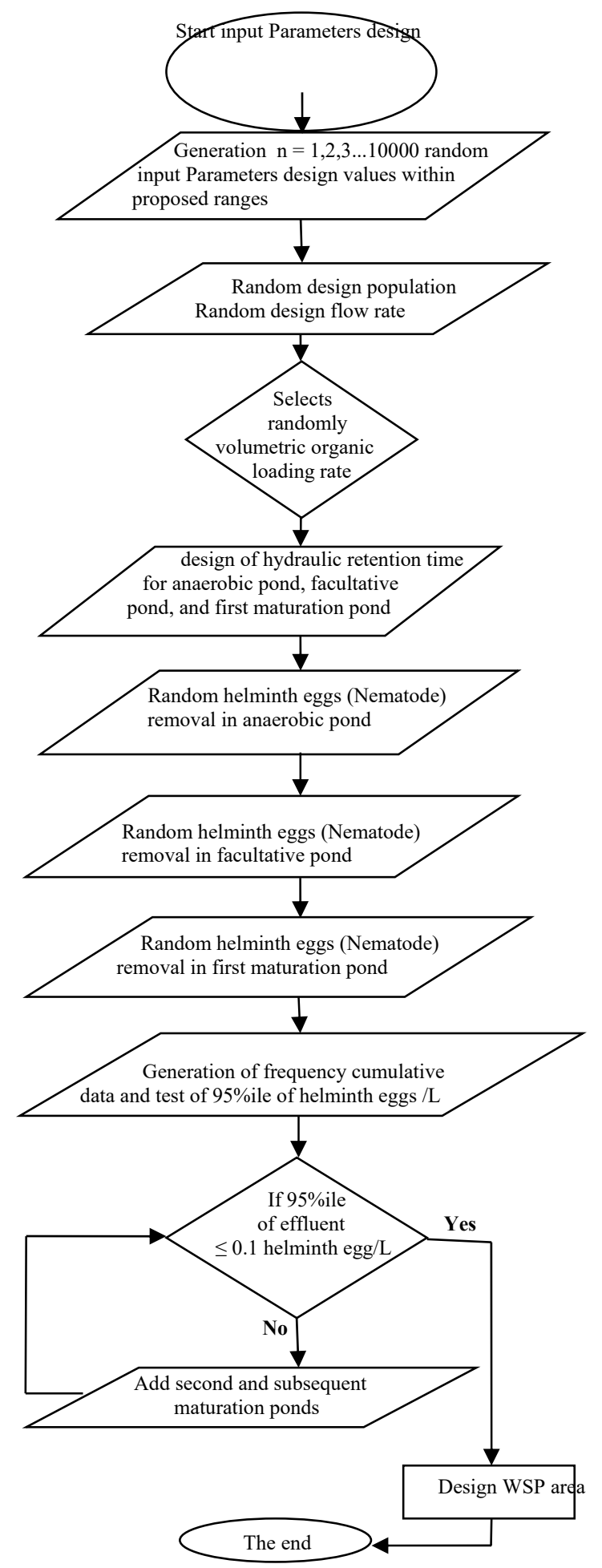

Fig. 5- Flowchart for the Monte Carlo simulation 
The Monte Carlo simulation methods work by selecting at random a value of each input design parameter and the coefficient of the models within a specified range, the ranges from (100 to 1000 eggs/L) for human intestinal helminth eggs. Other parameters based on $( \pm 20 \%)$ from median value. The procedures, based on parameter uncertainty and 10,000-trial. PC-based was developed for a series of anaerobic, facultative and maturation ponds. Finally, the output data were statistically analyzed as frequency cumulative data. The 95-\%ile value of effluent helminth eggs is selected from the frequency cumulative data and is compared with WHO, 2006 guidelines. If the effluent helminth eggs (Nematode) concentration is more than $(0.1$ helminth egg/L) the computer program adds subsequent maturation ponds until to satisfy the WHO, 2006 guidelines for the safe use of wastewater in agriculture.

\subsubsection{The design equations}

Generation the input design range: Monte Carlo simulation uses a uniform probability distribution to generate a range of the input design parameter. Vose [36], suggested that the cumulative probability distribution function for a uniform distribution of any range that has known end values could be expressed as an equation:

$F(x)=\frac{x-A}{B-A}$

where

$x=$ any random input design value within a range.

$A=$ the lower input design value of a range.

$B=$ the upper input design value of a range.

Monte Carlo simulation utilizes the inverse function of the cumulative density function, which according to Vose [36], is given in equation as follows:

$$
\begin{gathered}
F^{-1}(x i)=A+(B-A) v i \\
x i=A+(B-A) v i
\end{gathered}
$$

where

$v i=$ any random number value $(0-1)$.

The input range of the design parameters: Von Sperling [35], recommends that the lower and upper design values of the proposed range be determined by assuming a percentage value, which reflects the level of uncertainty of the average deterministic single value. the equations as follows:

$X_{\min }=\bar{X}-a \bar{X}$

$X_{\max }=\bar{X}+a \bar{X}$

where

$X_{\min }=$ lower end value of the input design range.

$X_{\max }=$ upper end value of the input design range.

$\bar{X}=$ average value of the input design parameter.

$a=$ any assumed percentage value based on the level of the uncertainty.

Design population: The design population is established by using equation as follows:

$P_{d}=P_{o}(1+r)^{n}$

where

$P_{d}=$ design population of the served community. 
$P_{o}=$ initial population of the served community.

$r=$ population growth rate.

$n=$ design period of waste stabilization ponds.

Design flow: The values of the population range are then used in equation for establishing the design flow range as follows:

$Q=\frac{P_{d} q}{1000}$

where

$Q=$ design flow rate $\left(\mathrm{m}^{3} /\right.$ day).

$P_{d}=$ design population.

$q=$ per capita wastewater production (1 per person per day).

Volumetric organic loading: At every run of a simulation, the computer program selects randomly the temperature from the proposed range and the selected temperature is compared with the four temperature conditions as suggested by Mara and Pearson [37], and Mara et al. [38].

The first temperature condition is satisfied when the selected random temperature $(T)<10^{\circ} \mathrm{C}$ as presented as follows:

$\lambda_{v}=100$

$\left(L_{i}\right)_{f}=0.6\left(L_{i}\right)_{a}$

$\left(L_{i}\right)_{m l}=0.3\left(L_{i}\right)_{a}$

where

$\lambda_{v}=$ volumetric organic loading rate $\left(\mathrm{g} / \mathrm{m}^{3}\right.$ day $)$.

$\left(L_{i}\right)_{a}=$ random design value of influent BOD in anaerobic pond $(\mathrm{mg} / \mathrm{l})$.

$\left(L_{i}\right)_{f}=$ influent BOD in facultative pond $(\mathrm{mg} / \mathrm{l})$.

$\left(L_{i}\right)_{m l}=$ influent BOD into first maturation pond $(\mathrm{mg} / \mathrm{l})$.

The second temperature condition is satisfied when the selected random temperature is between 10 and $20^{\circ} \mathrm{C}$ as presented as follows:

$\lambda_{v}=20 T-100$

$\left(L_{i}\right)_{f}=\frac{100-(2 T+20)}{100} \times\left(L_{i}\right)_{a}$

$\left(L_{i}\right)_{m l}=0.3\left(L_{i}\right)_{a}$

where

$T$ and $(L i)_{a}$ are random design parameters.

The third temperature condition is satisfied when the selected random temperature is between 20 and $25^{\circ} \mathrm{C}$ as presented as follows:

$\lambda_{v}=10 T+100$

$\left(L_{i}\right)_{f}=\frac{100-(2 T+20)}{100} \times\left(L_{i}\right)_{a}$
$\left(L_{i}\right)_{m l}=0.2\left(L_{i}\right)_{a}$ 
where

$T$ and $\left(L_{i}\right)_{a}$ are random design parameters. The fourth temperature condition is satisfied when the selected random temperature is above $25^{\circ} \mathrm{C}$ as presented as follows:

$\lambda_{v}=350$

$\left(L_{i}\right)_{f}=0.3\left(L_{i}\right)_{a}$

$\left(L_{i}\right)_{m l}=0.2\left(L_{i}\right)_{a}$

where

$\left(L_{i}\right)_{a}$ is a random design parameter.

The hydraulic retention time: The determination of the random value of the hydraulic retention time for the anaerobic pond is calculated as follows:

$\theta_{a}=\frac{\left(L_{i}\right)_{a}}{\lambda_{v}}$

where

the design parameters $\mathrm{Li}$, and $\lambda \mathrm{v}$ are random values selected from a proposed range in order to determine the random hydraulic retention time in anaerobic pond.

$\theta_{a}=$ hydraulic retention time (days).

$L_{i}=$ influent BOD concentration (mg/l).

$\lambda_{v}=$ volumetric BOD loading $\left(\mathrm{g} / \mathrm{m}^{3}\right.$ day).

The procedures for calculating the random hydraulic retention time for the facultative pond are presented as follows:

$\lambda_{s f}=350(1.107-0.002 T)^{\mathrm{T}-25}$ $10\left(L_{i}\right)_{f} Q_{f}$

$A_{f}=\overline{\lambda_{s f}}$

$\theta_{f}=\frac{2 A_{f} H_{f}}{\left(2 Q_{f}-0.001 e A_{f}\right)}$

where

$\left(2 Q_{f}-0.001 e A_{f}\right)$

the subscript " $f$ " refers to facultative pond.

the parameters $T,\left(L_{i}\right) f, Q_{f}, \lambda_{s f}, A_{f}$ and e are random design values.

$\theta_{f}=$ hydraulic retention time in facultative pond (days).

$\lambda_{s f}=$ surface BOD loading ( $\mathrm{kg} / \mathrm{ha}$ day $)$.

$T=$ temperature $\left({ }^{\circ} \mathrm{C}\right)$.

$A_{f}=$ facultative pond area $\left(\mathrm{m}^{2}\right)$.

$\left(L_{i}\right) f=$ influent BOD concentration in the facultative pond $(\mathrm{mg} / \mathrm{l})$.

$Q_{f}=$ mean flow $\left(\mathrm{m}^{3} /\right.$ day $)$.

$H_{f}=$ pond depth $(\mathrm{m})$.

$\mathrm{e}=$ net evaporation ( $\mathrm{mm} /$ day) .

The procedures for calculating the random hydraulic retention time for the first maturation pond are presented as follows:

$\lambda_{s f}=350(1.107-0.002 T)^{\mathrm{T}-25}$ 


$$
\theta_{m l}=\frac{10\left(L_{i}\right)_{m l} H_{m l}}{0.75 \lambda_{s f}}
$$

where

the subscript " $m l$ " refers to first maturation pond.

the parameters $T,(L i)_{m l}$ and $\lambda_{s f}$, are random design values.

$\theta_{m l}=$ minimum hydraulic retention time in first maturation pond (days).

$H_{m l}=$ design depth of the first maturation pond (m).

$\left(L_{i}\right)_{m l}=$ influent BOD concentration in first maturation pond $(\mathrm{mg} / \mathrm{l})$.

$\lambda_{s f}=$ surface BOD loading in facultative pond ( $\mathrm{kg} / \mathrm{ha}$ day).

The random design values of the hydraulic retention time in the second and subsequent maturation ponds is selected from the minimum retention time range of 3 to 5 days, as recommended by Marais [39].

Removal of human intestinal nematode eggs: The effluent helminth eggs concentration in the ponds is carried out by the design equation of Ayres et al. [40] as follows:

Removal of human intestinal nematode eggs in the anaerobic pond:

$R_{a}=100\left[1-0.41 \exp \left(-0.49 \theta_{a}+0.0085 \theta_{a}^{2}\right)\right]$

where

$R_{a}=$ the percentage egg removal in the anaerobic pond.

$\theta_{a}=$ the retention time in the anaerobic pond (days).

Removal of human intestinal nematode eggs in the facultative pond:

$R_{f}=100\left[1-0.41 \exp \left(-0.49 \theta_{f}+0.0085 \theta_{f}^{2}\right)\right]$

where

$R_{f}=$ the percentage egg removal in the facultative pond.

$\theta_{f}=$ the retention time in the facultative pond (days).

Removal of human intestinal nematode eggs in the first maturation pond:

$R_{m l}=100\left[1-0.41 \exp \left(-0.49 \theta_{m l}+0.0085 \theta_{m l}^{2}\right)\right]$

where

$R_{m l}=$ the percentage egg removal in the first maturation pond.

$\theta_{m l}=$ the retention time in the first maturation pond (days).

Removal of human intestinal nematode eggs in the second and subsequent maturation ponds:

$R_{m}=100\left[1-0.41 \exp \left(-0.49 \theta_{m}+0.0085 \theta_{m}^{2}\right)\right]$

where

$R_{m}=$ the percentage egg removal in the second and subsequent maturation ponds.

$\theta_{m}=$ the retention time in the second and subsequent maturation ponds (days).

Additionally, The equation is applied to the anaerobic pond, facultative pond and then to maturation ponds, to calculate the number of eggs per litre of the effluent, as follows:

$E=E_{\mathrm{rw}}\left(1-r_{\mathrm{an}}\right)\left(1-r_{\mathrm{fac}}\right)\left(1-r_{\text {matu } 1}\right)\left(1-r_{\text {matu }}\right)$

where

$E=$ the effluent number of Nematode eggs per litre.

$E_{\mathrm{rw}}=$ number of Nematode eggs per litre in the raw wastewater.

$r=R / 100$ with the subscripts 'an' 'fac' 'matul' 'matu' referring to the anaerobic pond, facultative pond, first maturation pond and the second and subsequent maturation ponds. 


\section{Results and Discussion}

As a result of Monte Carlo simulations models for the design of waste stabilization pond based on parameter uncertainty and 10,000-trial. A summary of the major types and functions of each pond is described in Table 5. Where we can see the highest number of human intestinal helminth eggs was removed in the anaerobic pond which a total removal efficiency (88.709\%) (figure 6) with a hydraulic retention (2.855 days) but the effluent still contained (105.288 eggs/l) (figure 7). Reasons that can explain Because, In anaerobic ponds, despite the high removal rate of suspended solids, the release of methane, hydrogen sulphide and carbon dioxide from the sludge layers leads to the resuspension of some organic and inorganic solids. It is possible that the relatively poor rate of removal of intestinal parasitic helminth eggs in anaerobic ponds is due to their resuspension by gas $[41,28]$.

Also, the Table 5 shows that numbers of helminth eggs in the effluent from facultative pond was (o.571 eggs/l) (figure 7). with a hydraulic retention (21.049 days) And the total efficiency removal which (99.938\%) (figure 6). The extremely the low efficiency Because anaerobic and facultative ponds are designed for removal of biochemical oxygen demand (BOD) and maturation ponds for pathogen removal. However, some BOD removal also occurs in maturation ponds and some pathogen removal in anaerobic and facultative ponds [42].

Table 5

Summary of data PC-Monte Carlo simulations for removal of human intestinal helminth eggs by waste stabilization ponds

\begin{tabular}{|c|c|c|c|c|c|}
\hline Pond type & $\begin{array}{l}\text { Area } \\
\text { (ha) }\end{array}$ & $\begin{array}{l}\text { Depth } \\
\text { (m) }\end{array}$ & $\begin{array}{l}\text { Design } \\
\text { Retention } \\
\text { time (d) }\end{array}$ & $\begin{array}{c}\text { Total } \\
\text { Efficiency } \\
(\%) \\
\end{array}$ & $\begin{array}{l}\text { Effluent } \\
\text { eggs/L }\end{array}$ \\
\hline $\begin{array}{c}\text { Raw } \\
\text { wastewater }\end{array}$ & & & & & 932.500 \\
\hline $\begin{array}{l}\text { Anaerobic } \\
\text { Pond }\end{array}$ & 0.418 & 4.00 & 2.855 & 88.709 & 105.288 \\
\hline $\begin{array}{c}\text { Facultative } \\
\text { Pond }\end{array}$ & 9.942 & 1.00 & 21.049 & 99.938 & 0.571 \\
\hline $\begin{array}{c}\text { First } \\
\text { maturation } \\
\text { Pond }\end{array}$ & 6.986 & 0.65 & 7.453 & 99.999 & 0.008 \\
\hline $\begin{array}{c}\text { First } \\
\text { addition } \\
\text { maturation } \\
\text { Pond } \\
\end{array}$ & 4.754 & 0.65 & 4.850 & 100 & 0.000 \\
\hline $\begin{array}{c}\text { The } \\
\text { overall }\end{array}$ & $\begin{array}{c}22.1 \\
\text { ha }\end{array}$ & & $\begin{array}{c}36.207 \\
\text { days }\end{array}$ & $100 \%$ & $\begin{array}{c}0.000 \\
\text { eggs/L }\end{array}$ \\
\hline
\end{tabular}

On the other hand, A series of anaerobic and facultative ponds can treat wastewater to a sufficient degree to allow it to be used in a restricted way for irrigating crops [19]. Anaerobic and facultative ponds only a relatively weak wastewater (up to $150 \mathrm{mg} \mathrm{BOD/1).} \mathrm{Maturation} \mathrm{ponds} \mathrm{are} \mathrm{required}$ only when the treated wastewater is to be used for unrestricted irrigation and when stronger wastewaters $(\mathrm{BOD}>150 \mathrm{mg} / \mathrm{l})[43,44]$. 


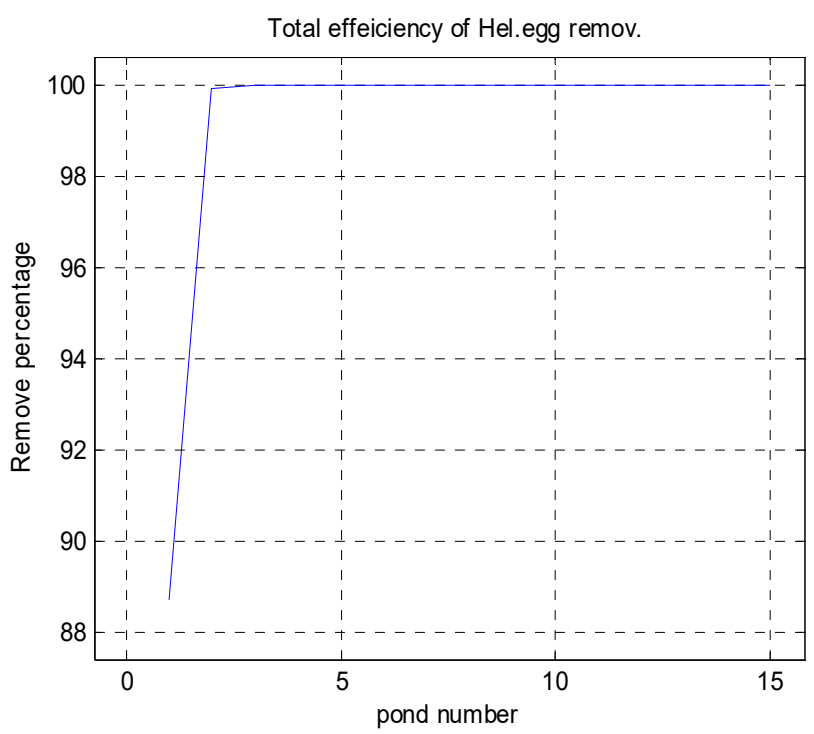

Fig. 6 - The total efficiency removal of helminth eggs in WSP

The extremely high removal of helminth eggs in maturation ponds is shown in Table 5 . While in the first maturation pond (figure 6) a total removal efficiency $(99.999 \%)$ and the effluent helminth eggs concentration was $(0.008$ eggs/l) with a hydraulic retention time (7.453 days) (figure 7$)$. Moreover, The total efficiency dramatically rose in the first addition maturation pond which (100 $\%)$ with effluent helminth eggs concentration ( 0.000 eggs/l). which the becomes less than WHO, 2006 guidelines for the safe use of wastewater in agriculture.

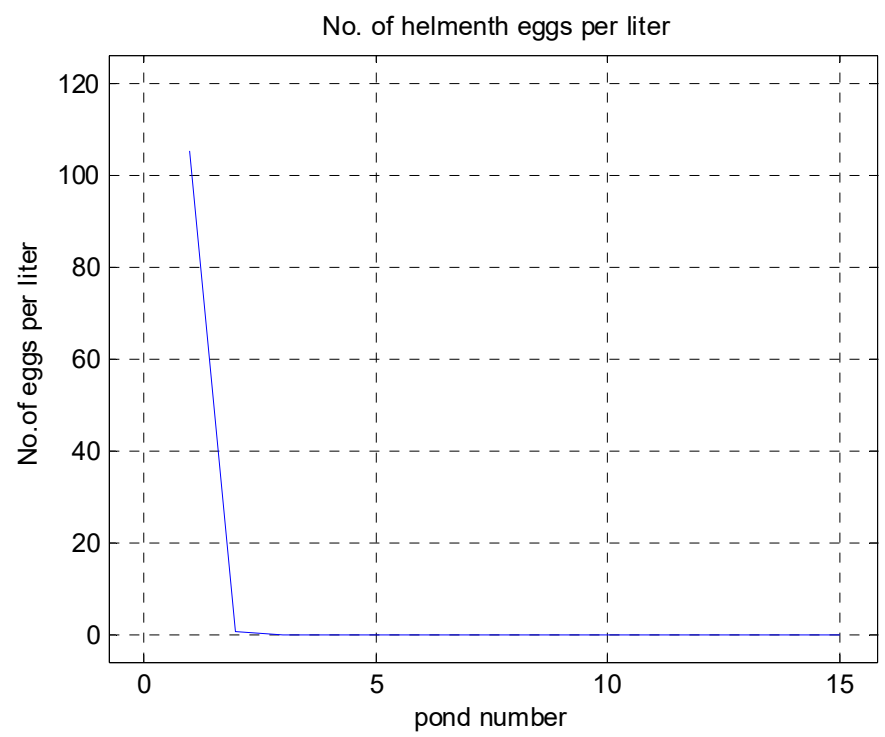

Fig. 7 - The effluent of helminth eggs from WSP

Possible reasons that can explain the high removal of helminth eggs in maturation ponds by the sedimentation Because the sedimentation is more effective in waste stabilization pond WSP with less turbulence. While the WSP systems have hydraulic retention times on the order of days, weeks, or even months, which allows particles to sedimentation [45]. Sedimentation is an important mechanism for the removal of those pathogens which can either settle on their own accord or attach to settleable particles. The degree to which pathogens adsorb onto settleable particles is influenced by both environmental conditions and the surface characteristics of the pathogens themselves through their influence on electrostatic, hydrophobic, and steric interactions [46]. This mechanism is considered to be important for both helminth eggs and protozoan cysts within WSPs, though recent studies have hypothesized that sunlight and physicochemical conditions of water could have a higher impact on cyst removal than previously thought $[47,48]$. 


\section{Conclusions}

In conclusions, That 36.207 days waste stabilization pond WSP in climatic conditions of Libya at Jalu municipality (anaerobic pond, facultative pond, first maturation pond and the first addition maturation ponds) produces an effluent of helminth eggs concentration less than WHO, 2006 guidelines for the safe use of wastewater in agriculture. Finally, the recycling of wastewater for agriculture may result in too high economic benefits that can offset the operation and maintenance costs of the ponds. However, there are also negative aspects related to wastewater reuse which include soil salinity, the health of farmers and consumers, public acceptability, marketability of produce, economic feasibility and sustainability of wastewater irrigation.

\section{References}

[1] Data and statistics. (2005). World Bank, 2000. (http://www.worldbank.org/data, accessed 7 April.

[2] Food and Agriculture Organization of the United Nations (FAO). (2012). Coping with water scarcity: An action framework for agriculture and food security. FAO Water Reports, No.38. Rome.

[3] Raschid-Sally, Liqa, and Priyantha Jayakody. (2008). Drivers and characteristics of wastewater agriculture in developing countries: Results from a global assessment. Colombo, Sri Lanka: International Water Management Institute. 35p. (IWMI Research Report 127).

[4] Food and Agriculture Organization of the United Nations (FAO). (2013). Wastewater reuse and agriculture: benefits for all Report on water issues 35, FAO, Rome.

[5] Nazari, R. Eslamian, S. Khanbilvardi, R. (2012). Water reuse and sustainability. In: Voudouris K (eds) Ecological water quality-Water treatment and reuse. InTech, Rijeka, Croatia and Shanghai, China 241-254.

[6] Gatto D'Andrea ML, Salas Barboza AGJ, Garcés V, Rodriguez-Alvarez MS, Iribarnegaray MA, et al. (2015). The Use of (Treated) Domestic Wastewater for Irrigation: Current Situation and Future Challenges. Int J Water and Wastewater Treatment 1(2): doi 2381-5299

[7] Carr, G. Potter, RB. Nortcliff, S. (2011). Water reuse for irrigation in Jordan: perceptions of water quality among farmers. Agric Water Manag 98: 847-854

[8] Hanjra, MA. Blackwell, J. Carr, G. Zhang, FH. Jackson, TM. (2012). Wastewater irrigation and environmental health: implications for water governance and public policy. Int J Hyg Environ Health 215:255-269

[9] Ahmed, W. Sidhu, JPS. Smith, K. Beale, DJ. Gyawali, P. Toze, S. (2016). Distributions of fecal markers in wastewater from different climatic zones for human fecal pollution tracking in Australian surface waters. Appl Environ Microbiol 82:1316-1323

[10] Petterson, SR. Stenström, TA. Ottoson, J. (2016). A theoretical approach to using faecal indicator data to model norovirus concentration in surface water for QMRA: Glomma River, Norway. Water Res 91:31- 37

[11] Amoah, ID. Reddy, P. Seidu, R. Stenström, TA. (2018). Removal of helminth eggs by centralized and decentralized wastewater treatment plants in South Africa and Lesotho: health implications for direct and indirect exposure to the effluents. Environ. Sci. Pollut. Res. 25:12883-12895

[12] Kamizoulis, G. (2008). Setting health based targets for water reuse (in agriculture). Science Direct 218 154-163.

[13] Yates, M.V. Gerba, C.P. (1998). Microbial considerations in wastewater reclamation and reuse. In: T. Asano, ed., Wastewater Reclamation and Reuse. Technomic Publishing Company, Lancaster, Pennsylvania, Chap. 10, pp. 1-56.

[14] Feachem, R.G. Bradley, D.J. Garelick, H. Mara, D.D. (1983). Sanitation and disease: health aspects of excreta and wastewater management. World Bank Studies in Water Supply and Sanitation 32, John Wiley \& Sons, Chichester

[15] Mara, D.D. Silva, S.A. (1986). Removal of intestinal nematode eggs in tropical waste stabilization ponds. J. Trop. Medicine Hygiene, 89(2) 71-74.

[16] Oragui, J.I. Curtis, T.P. Silva, S.A. Mara, D.D. (1987). Removal of excreted bacteria and viruses in deep waste stabilization ponds in northeast Brazil. Wat. Sci. Technol., 19 (Rio) 569-573.

[17] Jimenez-Cisneros, B.E. Maya-Rendon, C. (2007). Helminths and Sanitation. Communicating Current Research and Educational Topics and Trends in Applied Microbiology

[18] Atlas of Medical Parasitology, Intestinal parasites helminths, Tropical and Parasitology Service (2000). Amadeo di Savoia Hospital. The editor Editor Pietro Caramello MD.

[19] World Health Organisation. Health Guidelines for the use of wastewater in agriculture and aquaculture. (1989). Wld. Hlth. Org. Techn. Rep. Ser. No. 778.

[20] Horan, N. J. (1990). Biological Wastewater Treatment Systems "Theory and Operation”. John Willey \& Sons Ltd. New York.

[21] Al-Salem, S. S. Lumbers, J. P. (1987). An initial evaluation of Al-Samra waste stabilization ponds (Jordan). Water Science and Technology, 19 (12): 33-37.

[22] Bartone, C. R. Arlosoroff, S. (1987). Irrigation reuse of pond effluents in developing countries. Wat. Sci. Tech., 19 (12): 289-297. 
[23] Schwartzbrod, J. Bouhoum, K. Baleux, B. (1987). Effects of lagoon treatment on helminth eggs. Water Science and Technology, 19: 369-371.

[24] Mara, D. D. Pearson, H. W. Alabaster, G. Mills. S. (1990). An Evaluation Waste Stabilization Ponds in Kenya. ODA Research Scheme R4442A, Final Report.

[25] Saqqar, M. Pescod, M. B. (1991). Microbiological performance of multi-stage stabilization ponds from effluent use in agriculture. Water Science and Technology, 23 (7-9): 1517-1524.

[26] Saqqar, M. Pescod, M. B. (1992). Modeling nematode egg elimination in wastewater stabilization ponds. Water Science and Technology, 26 (7-8): 1659-1665.

[27] Ayres, R. M. Lee, D. L. Mara, D. D. Silva, S. A. (1993). The accumulation, distribution and viability of human parasitic nematode eggs in the sludge of primary facultative waste stabilisation pond. Transactions of the Royal Society of Tropical Medicine and Hygiene, 87 (2): 256-258.

[28] World Health Organization. Integrated Guide to Sanitary Parasitology. (2004). Regional office for the Eastern Mediterranean, regional centre for environmental health activities, Amman - Jordan

[29] WHO, Guidelines for the Safe Use of Wastewater, Excreta and Greywater, (2006). Vol. II, Wastewater Use in Agriculture, World Health Organization, United Nations Environmental Program, United Nations Food and Agriculture Organization, Geneva, Switzerland

[30] Libyan National Meteorological Center (LNMC) Climate Department

[31] APHA. Standard methods for the examination of water and wastewater, (1998). (20th edition, American Public Health Association, Washington DC, 1325).

[32] Ayres, R.M. Mara, D.D. (1996). Analysis of Wastewater for Use in Agriculture: A Laboratory Manual of Parasitoligical and Bacteriological Techniques. Geneva, Switzerland: World Health Organization

[33] Banda, C.G. (2003). Modern Design of Waste Stabilization Ponds in Warm Climates: Comparison with Traditional Design Methods. MSc. thesis, University of Leeds, Leeds, UK

[34] Banda, C.G. Sleigh, P.A. Mara, D.D. (2005). Escherichia coli removal in waste stabilization ponds: a comparison of modern and classical designs. Wat. Scie. \& Tech. Vol 51 No 12 pp 75-81

[35] Von Sperling, M. (1996). Design of facultative pond based on uncertainty analysis. Wat. Scie. \& Tech., 33 (7), 41-47

[36] Vose, D. (1996). Quantitative Risk Analysis: A Guide to Monte Carlo Simulation Modelling. John Wiley and Sons Ltd, Chichester, England.

[37] Mara, D.D. Pearson, H.W. (1986). Artificial freshwater environments: waste stabilization ponds. In Biotechnology, vol. 8 (ed. W. Schoenborn), pp. 177-206. VCH

[38] Mara, D.D. Pearson, H.W. Arridge, J.I. Arridge, H. Silva, S.A. .(1997). Development of a New Approach to Waste Stabilization Pond Design. TPHE Research Monograph

[39] Marais, G.V.R. (1974). Faecal bacterial kinetics in waste stabilization ponds. Journal of the Env. Eng. Divis., ASCE, 100 (EE1), 119-139

[40] Ayres, R.M. Alabaster, G.P. Mara, D.D. Lee, D.L. (1992). A design equation for human intestinal nematode egg removal in waste stabilization ponds. Water Research 26 (6), 863-865.

[41] Ayres, R. M. Mara, D. D. Lee, D. L. Thitai, W. N. (1993). Monitoring full scale waste stabilization pond in Kenya for Nematode egg removal. Environmental Technology, Vol. 14. pp 295-300.

[42] Mara, D. D. (1987). Waste stabilization ponds; Problems and controversies, Wat. Qual. Int., 1, 20-22

[43] Mara, D.D. (2004). Domestic wastewater treatment in developing countries, E./J. \& J., London, UK.

[44] Mara, D. D. Alabaster, G. P. Pearson, H. W. Mills, S. W. ( 1992). Waste stabilization ponds: A design manual for Eastern Africa, Lag. Techn. Intern., Leeds, England, 591 - 594.

[45] Verbyla, M. von Sperling, M. Maiga, Y. (2017). Waste Stabilization Ponds. In: J.B. Rose and B. JiménezCisneros, (eds) Global Water Pathogens Project.

[46] Templeton, M. R. Andrews, R. C. Hofmann, R. (2008). Particle-Associated Viruses in Water: Impacts on Disinfection Processes. Critical Reviews in Environmental Science and Technology, 38, 137-164

[47] Reinoso, R. Blanco, S. Torres-Villamizar L. A. Becares, E. (2011). Mechanisms for parasites removal in a waste stabilisation pond. Microbial Ecology, 61, 684-692

[48] Stratton, H. Lemckert, C. Roiko, A. Zhang, Wilson, H. S. Gibb, K. van der Akker, B. Macdonald, J. Melvin, S. Sheludchenko, M. Li, M., Xie, Padovan, J. A. Lehmann, R. (2015). Validation of maturation ponds in order to enhance safe and economical water recycling, Australian Water Recycling Centre of Excellence, Brisbane Australia. 